\title{
Thyroid function of steatitis-affected Mozambique tilapia Oreochromis mossambicus from a sub-tropical African reservoir
}

\author{
J. Dabrowski ${ }^{1,2, *}$, P. Oberholster ${ }^{3,4,5}$, J. Steyl ${ }^{3}$, G. Osthoff ${ }^{6}$, A. Hugo ${ }^{6}$, D. M. Power ${ }^{7}$, \\ J. H. van Wyk ${ }^{5}$ \\ ${ }^{1}$ Sustainability Research Unit, Nelson Mandela Metropolitan University, Private Bag x6531, George 6530, South Africa \\ ${ }^{2}$ Department of Zoology and Entomology, University of Pretoria, Hatfield 0028, South Africa \\ ${ }^{3}$ Department of Paraclinical Sciences, Faculty of Veterinary Science, University of Pretoria, Hatfield 0028, South Africa \\ ${ }^{4}$ CSIR Natural Resources and the Environment, PO Box 320, Stellenbosch 7599, South Africa \\ ${ }^{5}$ Department of Botany and Zoology, Stellenbosch University, Private Bag X1, Stellenbosch 7602, South Africa \\ ${ }^{6}$ Department of Microbial, Biochemical and Food Biotechnology, University of the Free State, PO Box 339, \\ Bloemfontein 9300, South Africa \\ ${ }^{7}$ Centro de Ciencias do Mar, Universidade do Algarve, Campus de Gambelas, Faro, 8005-139, Portugal
}

\begin{abstract}
Thyroid function and nutritional indicators were measured in obese, steatitisaffected Mozambique tilapia Oreochromis mossambicus from Loskop Reservoir (LR), South Africa. Plasma thyroid hormones (especially T3) and thyroid follicle histomorphology revealed high levels of activity in every aspect of the thyroid cascade measured in fish from LR compared to a reference population of steatitis-free fish. Concurrent measurements of nutritional state including plasma lipids, liver lipid content and hepatocyte size showed that fish from LR had significant energy stores indicative of abundant nutritional intake. There were distinct sex and seasonal differences, with the highest plasma lipids and T3 levels observed in steatitis-affected females during spring and summer. Positive correlations were observed between plasma lipids (especially cholesterol) and T3 concentrations in fish from both populations, indicating a link between lipid metabolism and thyroid function. There was no direct evidence of thyroid disruption, but this cannot be ruled out until further research determines the factors that underlie the homeostatic shift leading to elevated plasma and liver lipids and T3 levels in steatitis-affected tilapia.
\end{abstract}

KEY WORDS: Thyroid follicle $\cdot$ Pansteatitis · Obesity $\cdot$ Yellow fat disease $\cdot$ Olifants River $\cdot$ Loskop

\section{INTRODUCTION}

Pansteatitis, synonymous with yellow fat disease, is nutritionally mediated and characterised by degeneration, necrosis and inflammation of fat cells, with associated accumulations of ceroid pigment (SuarezBonnet et al. 2008, Huchzermeyer et al. 2011, Orós et al. 2013). Fat tissue affected by steatitis is yellow in colour which is why the disease is often referred to as yellow fat disease. Pansteatitis has been reported in various fish species, predominantly in an aquaculture setting (Roberts et al. 1979, Herman \& Kircheis 1985, Bricknell et al. 1996, Guarda et al. 1997, Goodwin 2006, Roberts \& Agius 2008). In captive-bred animals it is recurrently linked to consumption of a diet high in rancid or unsaturated fats, frequently of fish 
origin, and deficient in antioxidants such as vitamin E (Roberts et al. 1979, Fytianou et al. 2006, Roberts \& Agius 2008).

Pansteatitis is ubiquitous in the free-ranging Mozambique tilapia Oreochromis mossambicus (Peters, 1852) population in Loskop Reservoir (LR) in the upper catchment of the Olifants River, South Africa. O. mossambicus from LR are particularly large specimens. Many South African angling records have been set at this location, and the current International Game Fish Association world record fish weighing $3.11 \mathrm{~kg}$ was caught at LR in 2003. There is a high incidence of obesity in O. mossambicus from LR, characterised by abundant mesenteric fat leading to a distended abdomen. This is an important predisposing factor in the pathogenesis of pansteatitis because fish predominantly store polyunsaturated fat which is highly susceptible to lipid peroxidation, and in the presence of pro-oxidants, provides an extensive substrate for oxidative damage to occur (Lall 2010). Given the established links to dietary quality in captive-bred animals, piscivorous feeding behaviour or opportunistic scavenging on fish kills would be a plausible explanation for pansteatitis in O. mossambicus. However, this was regarded as highly unlikely in a study of their diet using a combination of stable isotopes and stomach contents (Dabrowski et al. 2014a). Their diet was described as herbivorous/detritivorous and was typical of other dietary studies in their native range. Food items were dominated by the dinoflagellate Ceratium hirundinella, followed by zooplankton, detritus and the cyanobacterium Microcystis aeruginosa.

In the mid- to late $2000 \mathrm{~s}$, large numbers of fish of several species, including O. mossambicus, and Nile crocodiles Crocodylus niloticus (Laurenti, 1768) died at LR. At approximately the same time, crocodile mortalities (>170 individuals) were reported downstream at the Olifants River gorge in Kruger National Park (KNP), South Africa's premier conservation area (Ferreira \& Pienaar 2011). Although factors such as pollution, drought and low dissolved oxygen were implicated in several of these events, mortalities of crocodiles at both locations and $O$. mossambicus at LR were linked to pansteatitis. Although rarely reported in other free-ranging fish species, the disease has also been described in African sharptooth catfish Clarias gariepinus (Burchell, 1822) in the KNP (Huchzermeyer et al. 2011), as well as in long rough dab Hippoglossoides platessoides (Fabricius, 1780) and common dab Limanda limanda (Linnaeus, 1758) from Scotland
(Begg et al. 2000). In all of these cases, the disease aetiology is unknown.

The Olifants River has been described as South Africa's 'hardest-working' river (Ashton \& Dabrowski 2011), with land uses in the upper catchment dominated by coal mining, coal-fired power generation, industry, agriculture and urban development (Dabrowski \& de Klerk 2013). LR acts as a sink for pollutants generated in the upper catchment (Dabrowski et al. 2013) and has become increasingly eutrophic, with frequent blooms of $M$. aeruginosa in summer and $C$. hirundinella in winter. In addition to elevated nutrient inputs, high concentrations of aluminium, iron, manganese and copper associated with acid mine drainage have been recorded (Oberholster et al. 2010, Dabrowski et al. 2013). Cyanotoxins and various metals are known to cause lipid peroxidation, and with no evidence of a fish-based dietary cause of pansteatitis, provide support for a contaminantinduced hypothesis.

The global increase in obesity rates has led to the study of metabolism as a target of endocrine disrupting contaminants. Thyroid function in fish may be influenced by many compounds including pharmaceuticals, pesticides, industrial chemicals and metals (Brown et al. 2004, Nugegoda \& Kibria 2017). Many of these compounds are likely present in the complex mixture of diluted effluents entering LR from wastewater treatment works, working and abandoned mines, industry and agricultural activities (Dabrowski \& de Klerk 2013). The current study focuses on the links between thyroid function and obesity in $O$. mossambicus.

\section{MATERIALS AND METHODS}

\section{Study site}

Oreochromis mossambicus were collected from the steatitis-affected population at LR and a reference population where steatitis has not been reported or observed at Flag Boshielo Reservoir (FBR). An extensive assessment of the water chemistry, physiography and limnology of both reservoirs was undertaken concurrent to fish sampling. In addition, historic trends in water quality were analysed for both reservoirs, and these results are available in Dabrowski et al. $(2013,2014$ b). The locations of the 5 sites in LR and 4 sites in FBR where monitoring was completed are shown in Fig. 1.

LR was constructed in 1937 to supply irrigation water to downstream agricultural areas via a net- 


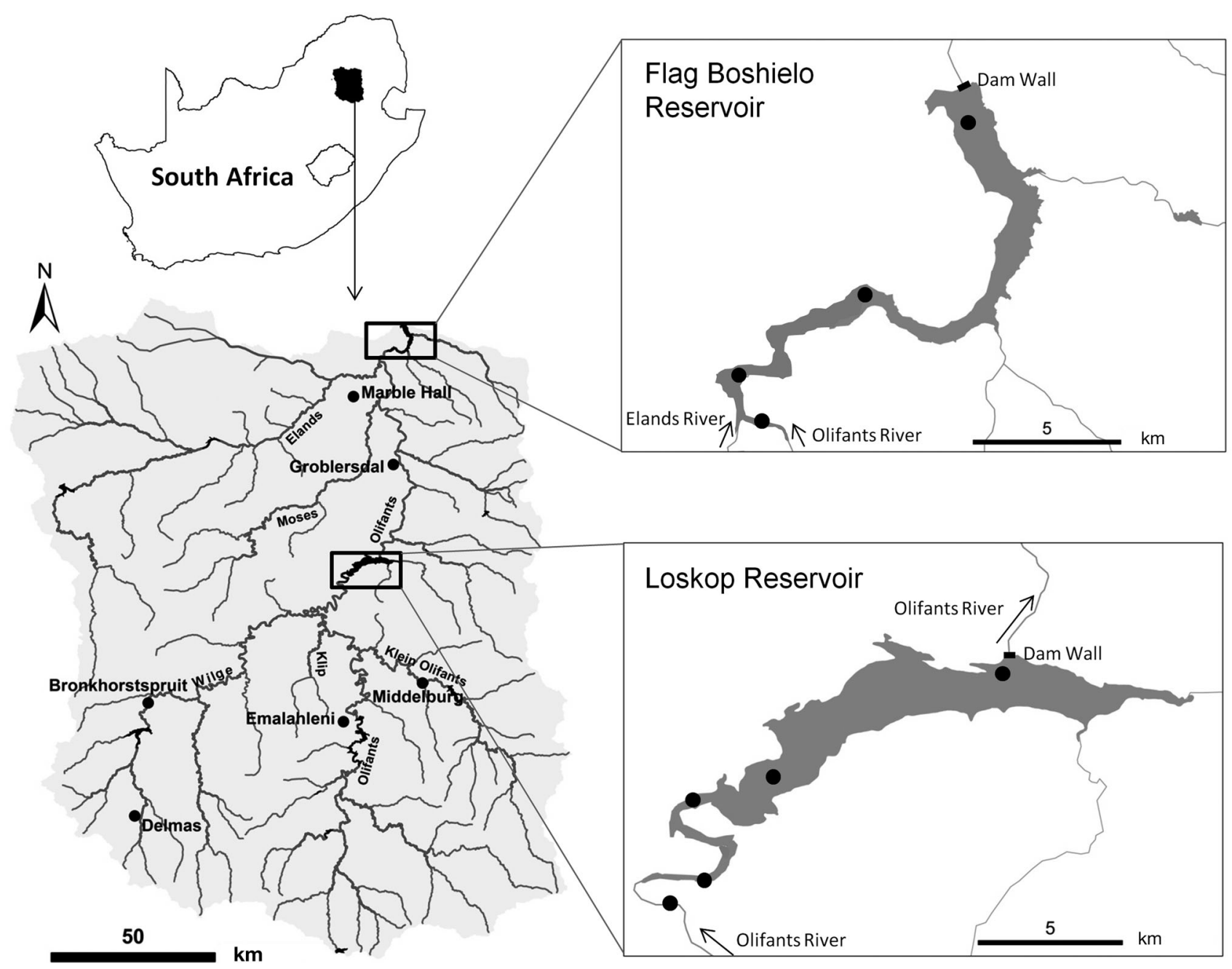

Fig. 1. Location of Loskop Reservoir (LR) and Flag Boshielo Reservoir (FBR) in the Olifants River catchment, South Africa. Solid circles indicate the location of water quality sampling sites assessed by Dabrowski et al. (2013, 2014b)

work of irrigation canals, and the main inflow is the Olifants River. During this study, the winter minimum water temperature was $15.4^{\circ} \mathrm{C}$ and the summer maximum was $32.2^{\circ} \mathrm{C}$. Catchment land uses affecting water quality include power generation, industry, agriculture and sewage treatment works associated with human settlements. Coal mining is prevalent, and the Witbank-Highveld coalfield produces $81 \%$ of South Africa's coal (DMR 2009). FBR was constructed in 1987 to supply water for irrigation, mining and municipal use. The main inflows are the Olifants and Elands Rivers, and the reservoir is located approximately $100 \mathrm{~km}$ downstream from LR. The minimum water temperature measured in winter was $19^{\circ} \mathrm{C}$ and the summer maximum was $31.8^{\circ} \mathrm{C}$. Catchment land use for FBR is dominated by dryland and irrigated agriculture.

\section{Fish collection}

Approximately 20 adult fish per season were collected from each reservoir using gill nets during April (autumn), June (winter), October (spring) and December (summer) in 2011 to incorporate seasonal variation related to feeding and reproductive cycles. Nets were set during daylight hours using $25 \mathrm{~m}$ panels ( $\mathrm{n}=3$ ) with 70,90 and $130 \mathrm{~mm}$ multi-filament stretched-mesh. An even sex ratio and consistent size class ( $>200 \mathrm{~mm}$ total length) was collected from each reservoir. Fish were weighed $(\mathrm{g})$ and measured (total length, $\mathrm{cm})$. Fulton's condition factor $(K)$ was calculated as $K=100 W L^{-3}$ where $W$ is body weight (g) and $L$ is length $(\mathrm{cm})$. Fish were transported to a field laboratory in a 2601 tank filled with water from the site and aerated with a mobile pump. After collection 
of blood samples, fish were euthanized by severing the cervical spinal cord. Routine necropsy followed euthanasia for tissue sampling purposes and macroscopical evaluation. Collection methods and animal handling were approved by the Animal Use and Care Committee of the University of Pretoria (approval VO17-10).

\section{Plasma lipids and thyroid hormones}

While fish were alive, a sample of blood was collected from the caudal vein. After centrifugation of whole blood, 2 aliquots were frozen at $-80^{\circ} \mathrm{C}$ for later analyses. One $0.5 \mathrm{ml}$ aliquot of plasma was for the analysis of total cholesterol and triglyceride concentrations (Wahlefeld 1974). Analyses were conducted on a Cobas Integra 400 chemistry analyser (Roche Diagnostics). Cholesterol concentrations were compared to reference intervals for Oreochromis hybrids in low-density production systems (Hrubec et al. 2000). The second $0.5 \mathrm{ml}$ aliquot of plasma was for analysis of total T3 and total T4 concentrations using Siemens Coat-A-Count $₫$ commercial kits by radioimmunoassay according to the manufacturer's guidelines. In order to measure total T3 and T4, the assay takes place in the presence of blocking agents which liberate bound thyroid hormones from carrier proteins. Sensitivity of the assay was defined by standards which ranged from 0.31 to $9.22 \mathrm{nmol} \mathrm{l}^{-1}$ for T3 and 6.4 to $193 \mathrm{nmol} \mathrm{l}^{-1}$ for T4. All samples were run in duplicate for each hormone in a single assay, and the intra-assay coefficient of variation (\% CV) was $3.26 \%$ for the T3 assay and $13.89 \%$ for the T4 assay. The assay was validated for use with $O$. mossambicus by comparing parallelism of the standard curve with serial dilutions of fish serum. Concentrations of T4 were too low for the dilution series, but parallelism was shown for T3 concentrations, which indicated that fish plasma proteins did not interfere with the assays. As an indicator of peripheral conversion of T4 to T3 (5'-deiodination), the ratios of T3:T4 were calculated (Brar et al. 2010).

\section{Histomorphology of thyroid follicles and liver}

The ventral pharyngeal and basal gill arch tissue of a sub-sample of 30 fish from each reservoir was dissected and fixed in $10 \%$ buffered $(\mathrm{pH}$ 6.5-6.8, $\mathrm{CaCO}_{3}$ ) formaldehyde solution for histomorphological analysis of thyroid follicles. Approximately even sex ratios were evaluated, with 14 females and 16 males from LR, and 17 females and 13 males from FBR. Thyroid tissue was not collected from fish sampled during winter; therefore, this season was excluded from the analysis. Liver tissue was also collected and fixed from the fish, as well as an additional 10 fish sampled during winter from both reservoirs, allowing a complete seasonal comparison. Plasma T3, T4, cholesterol and triglycerides were measured in the blood of fish used for histomorphology. Tissue sections were processed and stained with haematoxylin and eosin (H\&E) following standard methods (Bancroft \& Gamble 2002). All tissue sections (thyroid follicles and liver) were analysed with an Olympus BX43 light microscope fitted with an AxioCam ICc 3 Zeiss microscope camera, and all parameters were measured using image analysis software (AxioVision 4).

\section{Thyroid follicle assessment}

Tissue sections were selected from those available on the slide depending on the most numerous intact thyroid follicles. Ten thyroid follicles were selected from each of the 30 sub-sampled fish, and the perimeter $(\mu \mathrm{m})$ and area $\left(\mu \mathrm{m}^{2}\right)$ of each follicle were measured. These parameters are a reliable indirect measurement of thyroid stimulating hormone (TSH) (Eales \& Brown 1993) and were used to measure thyroid gland function (Carr \& Patiño 2011). For each follicle, the number of colloid vacuoles along the inner perimeter was counted (colloid vacuoles $\mu \mathrm{m}^{-1}$ ), and the epithelial cell heights of 3 thyrocytes were measured. The appearance of H\&E-stained colloid within each follicle was subjectively scored for nonspecific protein concentration (Fischer et al. 2008), with lower values indicating depleted levels, and higher values indicating more concentrated storage: $0=$ empty; 1 = granular appearance; 2 = light eosinophilic stain; 3 = intense eosinophilic stain (see Fig. 3 for an example). Even though non-specific, the follicular protein concentration in the follicles should directly reflect thyroglobulin concentration, as it is the most abundant protein produced by thyrocytes. The mean score for colloid abundance for 10 follicles fish $^{-1}$ is presented as the average colloid density.

\section{Liver assessment}

One of the methods commonly used to assess the nutritional status of fish is to measure the size (circumference, diameter or area) of hepatocytes (Power 
et al. 2000, Lu et al. 2013). The extent of individual hepatocytes was difficult to distinguish, as their outline was unclear, so an alternative method was devised. Hepatocyte density was measured by counting all the visible nuclei in a rectangular frame measuring $180 \times 130 \mu \mathrm{m}$ placed in 5 random, non-overlapping areas of the liver. Each frame was examined at $40 \times$ magnification. The size (area in $\mu^{2}$ ) of 10 randomly selected nuclei per frame was measured, as this has been suggested to be a good indicator of nutritional status (Strüssmann \& Takashima 1990, Power et al. 2000).

\section{Liver lipid and moisture content determination}

Liver samples were dissected from each of the fish in the thyroid follicle assessment, including a sub-sample of 10 fish collected during winter. Samples were kept frozen prior to analyses. Total lipids from liver samples were quantitatively extracted according to the method of Folch et al. (1957), using chloroform and methanol at a ratio of $2: 1$. Solvents were removed from the dry fat extracts by evaporation, and the extracts were further dried overnight in a vacuum oven at $50^{\circ} \mathrm{C}$, using phosphorus pentoxide as a moisture adsorbent. Total extractable fat was determined gravimetrically and expressed as \% fat per $100 \mathrm{~g}$ wet tissue. The moisture content was determined by weight difference before and after drying tissue to a constant weight.

\section{Statistical analysis}

Thyroid hormone data violated parametric test assumptions of normality and homogeneity of variance which were improved using a Box-Cox transformation. Transformed data were analysed using a multi-factor analysis of variance (MANOVA) using disease status (steatitis or reference), gender and season as predictor variables. Post hoc comparisons were made using a Tukeys's HSD test.

Thyroid follicle histomorphology, plasma cholesterol and triglycerides, and liver measurements were analysed using a MANOVA with disease status, season and gender as factors. Measurements from 10 thyroid follicles fish ${ }^{-1}$ were used to calculate mean values that were used in the analysis, and variables were transformed to meet assumptions where necessary. To determine whether fish size influenced the measured endpoints, the rela- tionship between fish TL and all parameters was assessed using a Spearman's rank correlation. No significant correlations were found and therefore fish length was not used as a covariate in any statistical analyses. Relationships between measured parameters were evaluated using a stepwise multiple regression analysis. All variables were assessed for collinearity and if found to be significantly correlated, one of the variables was removed from the analysis. All statistical analyses were conducted using Statistica Version 12 (StatSoft), and the significance level $(\alpha)$ was set at 0.05 .

\section{RESULTS}

\section{Fish}

All fish collected from LR had abundant abdominal (mesenteric) fat which contained clearly visible lesions typical of pansteatitis, characterised by yellow, orange and brown (ceroid pigment) clearly demarcated consolidated masses ranging from multifocal $1 \mathrm{~mm}$ pin point to large coalescing irregularly shaped foci. These foci were histopathologically confirmed (University of Pretoria, Faculty of Veterinary Science, Section of Pathology) as multifocal, well demarcated regions of granulomatous steatitis characterised by injured (necrotic) adipocytes filled with saponified and oxidised lipids surrounded and infiltrated by numerous lipid-laden macrophages. All fish collected from FBR had little to no fat, which, when present, was off-white in colour and contained no pansteatitis lesions. A single-factor ANOVA showed that the mean body mass, total length and condition factor were all significantly greater in steatitisaffected fish than in reference fish (ANOVA, $F_{3,166}=38.26, \mathrm{p}<0.0001$ ). The mean body mass of steatitis-affected fish was approximately double the mean body mass of reference fish (Table 1).

\section{Plasma thyroid hormones}

Plasma T3 levels in steatitis-affected fish from LR were significantly higher in fish from LR than in reference fish from FBR (MANOVA, $F_{1,122}=278.33, \mathrm{p}<$ $0.0001)$. The interaction between disease status and season was significant, with levels of T3 in fish from LR showing an increasing trend from autumn through to summer, while T3 showed no significant seasonal variation in reference fish from FBR 
Table 1. Summarised catch statistics for steatitis-affected Oreochromis mossambicus sampled from Loskop Reservoir and reference fish from Flag Boshielo Reservoir in 2011 including the sex ratio (male:female, M:F), body mass, total length (TL) and condition factor $(K)$; values are means \pm SD. Statistics are based on single-factor ANOVA using disease status as a factor; ${ }^{* * *} \mathrm{p}<0.001$

\begin{tabular}{|lccclc|}
\hline $\begin{array}{l}\text { Disease status } \\
\text { Season }\end{array}$ & $\mathrm{n}$ & $\mathrm{M}: \mathrm{F}$ & Body mass $(\mathrm{g})$ & $\mathrm{TL}(\mathrm{mm})$ & $K$ \\
\hline Steatitis & & & & & \\
$\quad$ Autumn & 31 & $17: 14$ & $1207 \pm 597$ & $372 \pm 6.5$ & $2.1 \pm 0.3$ \\
Winter & 20 & $7: 13$ & $1725 \pm 468$ & $421 \pm 3.9$ & $2.3 \pm 0.2$ \\
Spring & 20 & $11: 9$ & $1683 \pm 337$ & $420 \pm 3.4$ & $2.8 \pm 0.2$ \\
Summer & 20 & $6: 14$ & $1353 \pm 448$ & $395 \pm 4.8$ & $2.1 \pm 0.2$ \\
Total & 91 & $41: 50$ & $1458 \pm 532^{* * *}$ & $398 \pm 5.4^{* * *}$ & $2.2 \pm 0.2^{* * *}$ \\
Reference & & & & & \\
Autumn & 21 & $16: 5$ & $876 \pm 404$ & $365 \pm 6.3$ & $1.9 \pm 0.2$ \\
Winter & 20 & $15: 5$ & $906 \pm 312$ & $353 \pm 4.8$ & $2.0 \pm 0.2$ \\
Spring & 20 & $7: 13$ & $662 \pm 252$ & $321 \pm 5.2$ & $1.9 \pm 0.2$ \\
Summer & 20 & $4: 16$ & $474 \pm 223$ & $283 \pm 3.8$ & $1.9 \pm 0.1$ \\
Total & 81 & $42: 39$ & $730 \pm 348^{* * *}$ & $325 \pm 5.7^{* * *}$ & $1.9 \pm 0.2^{* * *}$ \\
& & & & & \\
\hline
\end{tabular}

(Table 2). Steatitis-affected fish had significantly larger thyroid follicles with a greater epithelial cell height, and more colloid vacuoles along the follicle epithelium (Table 2, Fig. 3). Fish with steatitis had significantly lower average colloid storage than reference fish (Table 2, Fig. 3).

\section{Plasma cholesterol and triglycerides}

Disease status had a significant effect on both cholesterol (MANOVA, $F_{1,129}=$ 127.28, p $<0.0001$ ) and triglyceride (MANOVA, $\left.F_{1,129}=6.88, \mathrm{p}<0.01\right)$ concentrations, with higher concentrations of both plasma lipids in steatitisaffected fish (Fig. 4). Both cholesterol levels (MANOVA, $F_{3,129}=2.76, \mathrm{p}<$ 0.05) and triglycerides (MANOVA,

(MANOVA, $\left.F_{3,122}=8.25, \mathrm{p}<0.0001\right)$. Female fish had significantly higher T3 levels than male fish from both populations (MANOVA, $F_{1,122}=4.26$, p < 0.05). Total plasma T4 levels were slightly higher in steatitis-affected fish compared to reference fish (MANOVA, $\left.F_{1,121}=5.17, \mathrm{p}<0.05\right)$. There was no difference in T4 levels between both fish populations in any seasons except summer, when T4 was higher in steatitis-affected fish (MANOVA, $F_{3,121}=3.62, \mathrm{p}<$ 0.05). Female fish from both populations had slightly higher T4 levels than males (MANOVA, $F_{1,121}=5.61$, $\mathrm{p}<0.05)$, but there was no interaction effect between gender and disease status. The T3:T4 ratio was significantly higher in steatitis-affected fish than in reference fish (MANOVA, $\left.F_{3,116}=68.03, \mathrm{p}<0.001\right)$. The T3:T4 ratio showed a decreasing trend over the duration of the study in both fish populations, which was particularly evident in the reference fish (MANOVA, $\left.F_{3,116}=3.03, \mathrm{p}<0.05\right)$. The ratio was not affected by fish gender, and results were therefore pooled according to disease status and season in Fig. 2. Results of Tukey's HSD post hoc analysis are presented in Fig. 2.

\section{Thyroid follicle histomorphology}

All 4 follicle descriptors were significantly affected by disease status (MANOVA, $F_{4,45}=8.3$, $\mathrm{p}<0.001$ ) as a factor. Neither gender nor season had a significant effect on any of the descriptors, so the results were grouped by disease status
$\left.F_{3,129}=7.44, \mathrm{p}<0.001\right)$ were significantly affected by season, with higher levels in spring and summer in fish from both populations. The interaction between gender and season was significant for both cholesterol (MANOVA, $F_{3,129}=7.06, \mathrm{p}<$ 0.001 ) and triglycerides $\left(\mathrm{MANOVA}, F_{3,129}=8.68\right.$, $\mathrm{p}<0.0001$ ), with higher concentrations in female fish in spring and summer in both reference and steatitis-affected fish. Female fish with steatitis consistently had the highest cholesterol and triglyceride levels of all fish sampled, and exceeded the published reference interval for cholesterol for tilapia hybrids during each season (Fig. 4a; Hrubec et al. 2000). Although female reference fish showed similar seasonal variation, their cholesterol levels were consistently within the reference range (Fig. 4a).

Table 2. Mean \pm SE histological and morphometric descriptor values for thyroid follicles $\left(10 \mathrm{fish}^{-1}\right)$ evaluated in steatitis-affected Oreochromis mossambicus from Loskop Reservoir $(\mathrm{N}=30)$ and reference fish from Flag Boshielo Reservoir $(\mathrm{N}=30)$. Significance is for Tukey's HSD post hoc analysis of the effect of disease status; ${ }^{* *} \mathrm{p}<0.01,{ }^{* * *} \mathrm{p}<0.001$

\begin{tabular}{|lrc|}
\hline Thyroid follicle descriptors & Steatitis & Reference \\
\hline Area $\left(\mu \mathrm{m}^{2}\right)^{\mathrm{a}}$ & $64005 \pm 9562^{* *}$ & $25639 \pm 4118^{* *}$ \\
Epithelial cell height $(\mu \mathrm{m})$ & $4.5 \pm 0.1^{* * *}$ & $3.5 \pm 0.1^{* * *}$ \\
Colloid vacuoles $\left(\mathrm{nm}^{-1}\right)^{\mathrm{b}}$ & $39.57 \pm 3.66^{* *}$ & $23.87 \pm 3.25^{* *}$ \\
Average colloid storage & $2.02 \pm 0.07^{* *}$ & $2.30 \pm 0.05^{* *}$ \\
${ }^{\mathrm{a}}$ Log transformed & \\
b Square root transformed for statistical analysis \\
\hline
\end{tabular}




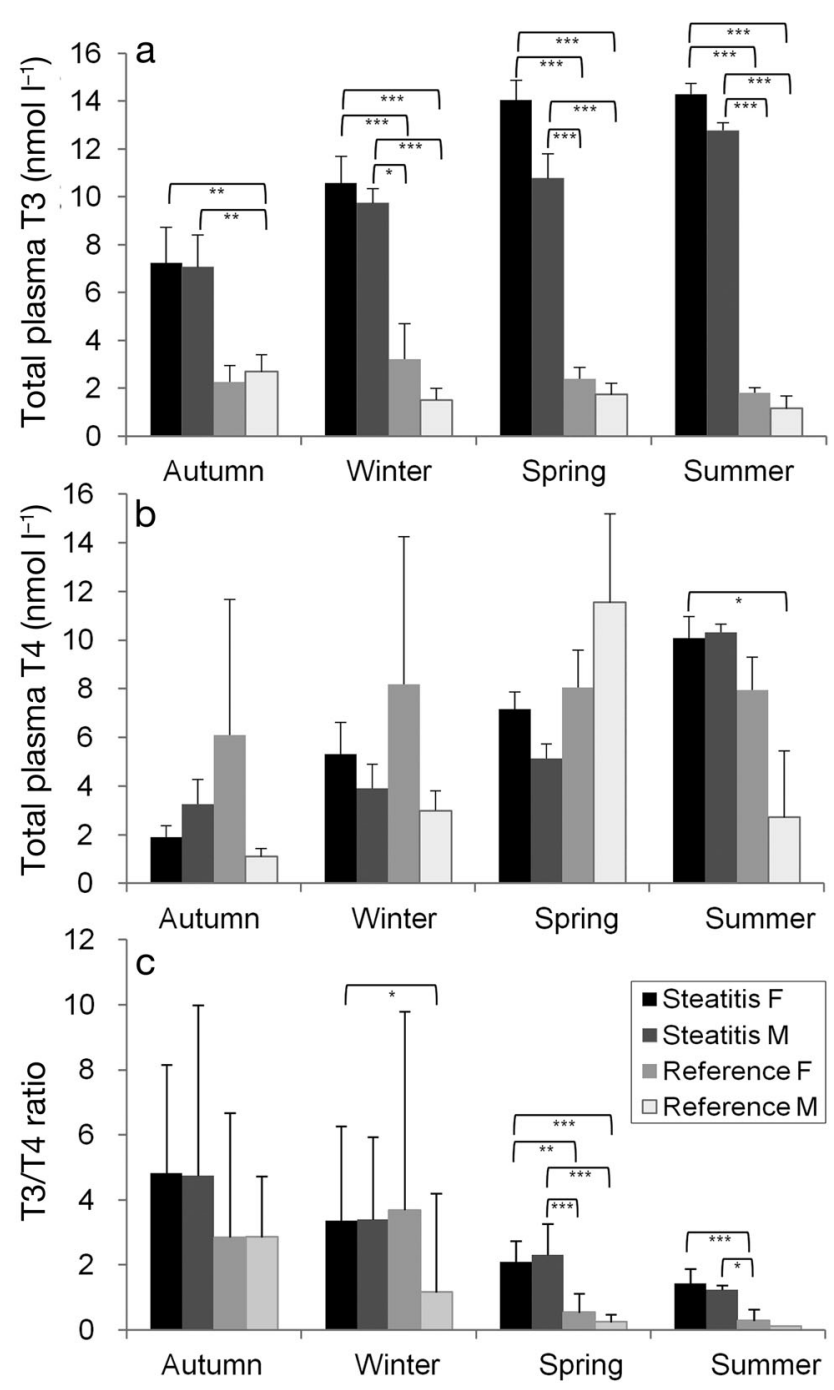

Fig. 2. Plasma (a) T3 and (b) T4 concentrations, and (c) the T3:T4 ratio measured in steatitis-affected and reference Oreochromis mossambicus (F: females; M: males) sampled from Loskop Reservoir (LR) and Flag Boshielo Reservoir (FBR), respectively. Bars represent mean values $\pm \mathrm{SE}$. Results of Tukey's post hoc analyses are indicated where statistically significant between groups: ${ }^{*} p<0.05,{ }^{* *} p<$ $0.01,^{* * *} \mathrm{p}<0.001$

\section{Hepatocyte histomorphology}

Extensive lipid vacuolisation was generally evident in hepatocytes of steatitis-affected fish, even during winter months (Fig. 5a). Hepatocytes of reference fish were frequently atrophied, with depleted lipid reserves and prominent sinusoids (Fig. 5b). Hepatocyte density was significantly lower in fish with steatitis with a high degree of variation (MANOVA, $F_{1,64}=24.85, \mathrm{p}<0.0001$; Table 3 ), which is equivalent to increased cell area by comparison to reference
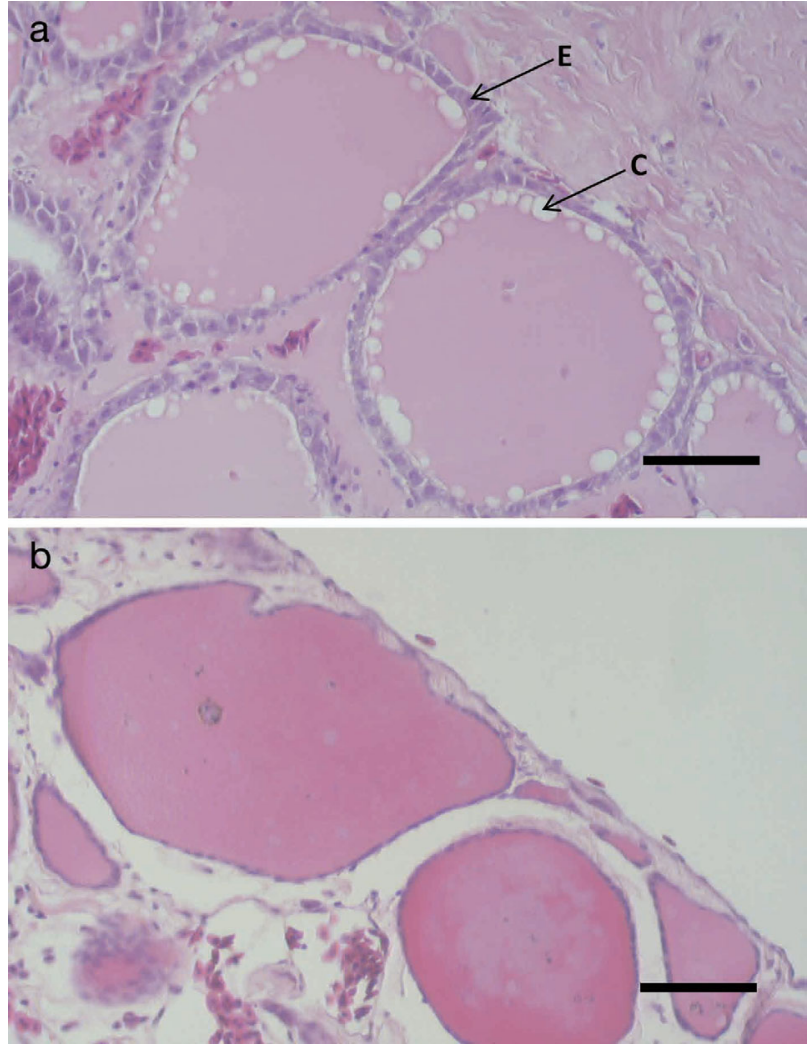

Fig. 3. Photomicrographs (H\&E stain) of Oreochromis mossambicus thyroid follicles from (a) steatitis-affected and (b) reference fish showing typically greater epithelial cell height (E), number of colloid vacuoles (C) and lower colloid storage in steatitis-affected fish. Similar sized follicles have been selected for ease of comparison. Colloid density was scored as 2 (light eosinophilic stain) in (a) and as 3 (intense eosinophilic stain) in (b). Scale bars $=50 \mu \mathrm{m}$

fish. This parameter was not significantly affected by season $\left(F_{3,64}=0.6, \mathrm{p}=0.59\right)$ or $\operatorname{sex}\left(F_{1,64}=1.3, \mathrm{p}=\right.$ $0.24)$. The nuclear area of hepatocytes was significantly larger in steatitis-affected fish $\left(F_{1,64}=9.08, \mathrm{p}<\right.$ 0.01 ; Table 3$)$, but was not significantly affected by season $\left(F_{3,64}=2.7, \mathrm{p}=0.49\right)$ or $\operatorname{sex}\left(F_{1,64}=0.4, \mathrm{p}=\right.$ $0.82)$. The interaction between disease status and gender was significant $\left(F_{1,64}=6.2, \mathrm{p}<0.05\right)$, with larger nuclei in steatitis-affected females than in reference females.

\section{Liver lipid and moisture content}

The mean liver lipid content in fish with steatitis was significantly higher than that of reference fish (MANOVA, $F_{1,61}=28, \mathrm{p}<0.0001$; Fig. 6a). Liver moisture content was lower in fish with steatits 

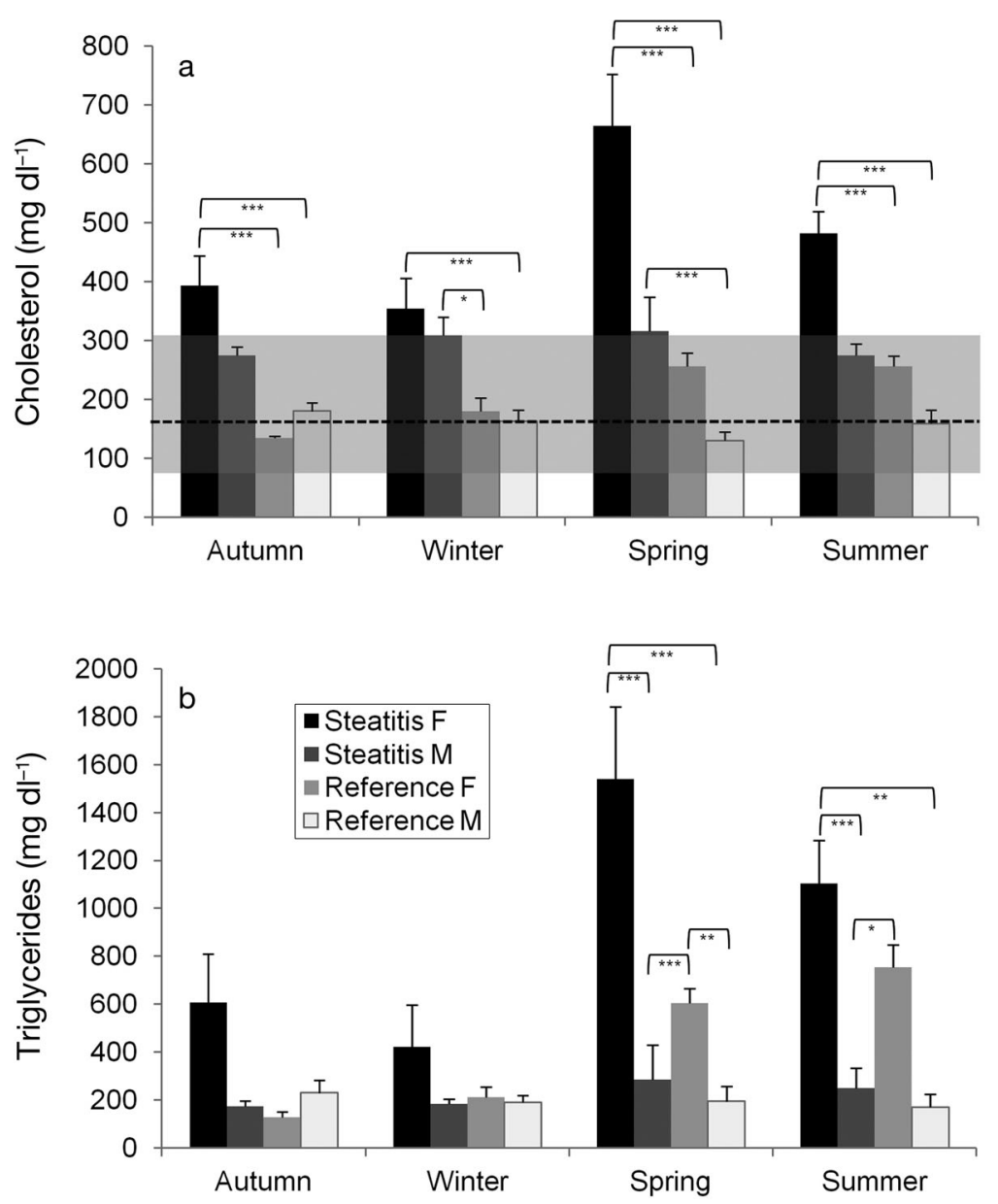

Fig. 4. Concentrations of (a) cholesterol and (b) triglycerides (mean \pm $\mathrm{SE})$, measured in steatitis-affected and reference Oreochromis mossambicus (F: female; M: male). Dashed horizontal line and shaded area for cholesterol indicate the respective range and median reference intervals for Oreochromis hybrids (Hrubec et al. 2000). Results of Tukey's post hoc analyses are indicated where statistically significant between groups: ${ }^{*} \mathrm{p}<0.05,{ }^{* *} \mathrm{p}<0.01,{ }^{* * *} \mathrm{p}<0.001$

than in reference fish (MANOVA, $F_{1,61}=29, \mathrm{p}<$ 0.0001; Fig. 6b). Neither liver lipid nor moisture content were significantly affected by season or gender, and there were no significant interaction effects.

\section{Relationships between thyroid and nutritional status}

When 2 variables were significantly correlated, 1 was removed from the stepwise regression analysis. In fish from both reservoirs, liver lipid was negatively correlated with liver \% moisture, and cholesterol was positively correlated with triglycerides. In both cases, the latter variable was removed.

The T3 concentrations in steatitisaffected fish were positively correlated with the T3:T4 ratio, colloid vacuoles $\mathrm{nm}^{-1}$ and cholesterol levels (Table 4). Both colloid storage and hepatocyte density were negatively correlated with T3 levels. The T3:T4 ratio was positively correlated with T3 levels and negatively correlated with T4 levels. In reference fish, thyroid follicle size was positively correlated with the T3:T4 ratio and cholesterol was positively correlated with T3. The latter is consistent with the steatitis-affected fish.

\section{DISCUSSION}

With the exception of plasma T4 levels, every aspect of the thyroid cascade examined in steatitis-affected Oreochromis mossambicus from LR indicated very high levels of activity in comparison to the reference fish from FBR. The finding that T3 was positively correlated with the number of colloid vacuoles and negatively correlated with colloid storage is a strong indicator that thyroid follicles were actively producing T4 for conversion to T3. Elevated epithelial cell height, decreased colloid staining and a greater number of colloid vacuoles within thyroid follicles are all indirect but reliable indicators that TSH was being actively released by the pituitary gland (Eales \& Brown 1993). These results also indicated that $\mathrm{T} 4$ was being actively synthesized and secreted, and no clear disruption was detected at this level of the

Table 3. Mean \pm SD density and nucleus size $\left(\mu m^{2}\right)$ of hepatocytes for male and female Oreochromis mossambicus from Loskop Reservoir (steatitis-affected) and Flag Boshielo Reservoir (reference condition)

\begin{tabular}{|lcc|}
\hline & $\begin{array}{c}\text { Hepatocyte density } \\
\text { (no. frame }\end{array}$ & $\begin{array}{c}\text { Hepatocyte } \\
\text { nucleus size }\end{array}$ \\
\hline Steatitis females & $70.5 \pm 0.1$ & $18.1 \pm 2.0$ \\
Steatitis males & $59.8 \pm 0.1$ & $17.1 \pm 1.5$ \\
Reference females & $95.7 \pm 27.9$ & $16.4 \pm 1.5$ \\
Reference males & $91.4 \pm 33.6$ & $16.7 \pm 1.5$ \\
\hline
\end{tabular}



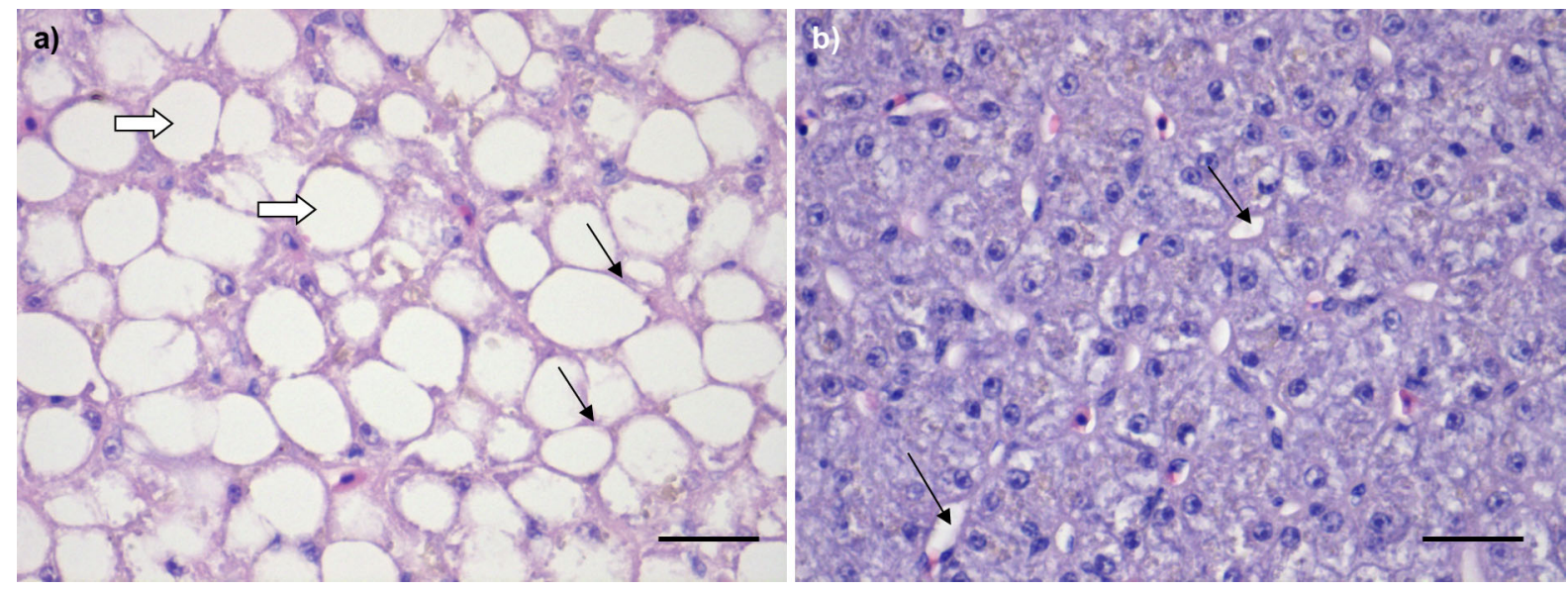

Fig. 5. Photomicrographs (H\&E stain) of Oreochromis mossambicus liver sections collected during winter from (a) steatitisaffected fish from Loskop Reservoir, where extensive lipid vacuolisation was frequently evident (white arrows) resulting in hypertrophied hepatocytes, and narrower sinusoids (black arrows); (b) reference fish from Flag Boshielo Reservoir, where cell area was reduced, sinusoids were more prominent (black arrows), and vacuolisation was minimal. Scale bars $=20 \mu \mathrm{m}$
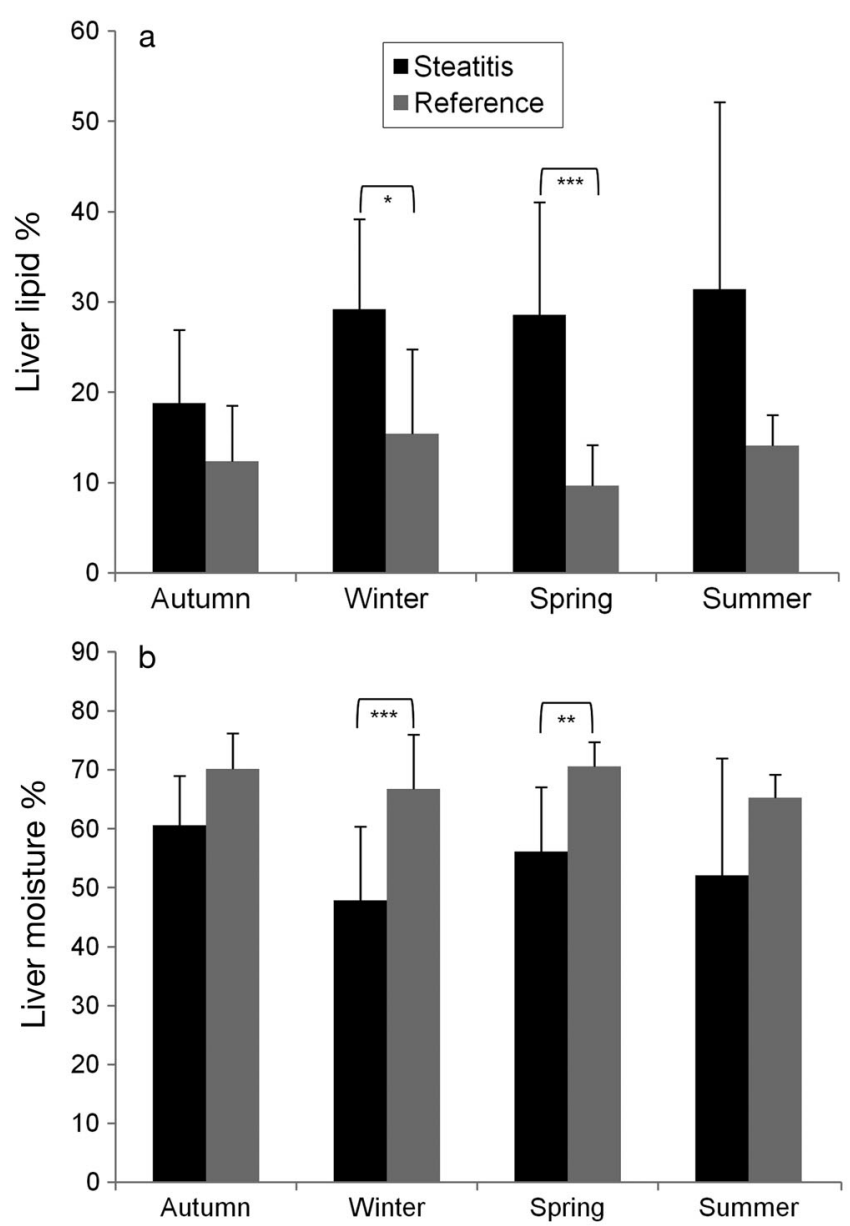

Fig. 6. Mean ( \pm SD) liver (a) lipid and (b) moisture levels (\%) measured in steatitis-affected and reference Oreochromis mossambicus from Loskop Reservoir and Flag Boshielo Reservoir, respectively. Results of Tukey's post hoc analyses are indicated where statistically significant between groups: ${ }^{*} \mathrm{p}<0.05,{ }^{* *} \mathrm{p}<0.01,{ }^{* * *} \mathrm{p}<0.001$ thyroid cascade. This was further confirmed by the similar T4 concentrations observed in fish from both populations, which emphasised the homeostatic capacity of the thyroid system at the central level as has been previously observed (Eales et al. 1999, Van der Geyten et al. 2005).

A related study investigated the expression of selected genes associated with the thyroid and adrenal endocrine axes of pansteatitis-affected $O$. mossambicus from LR (Truter et al. 2016). Fish with pansteatitis from LR had elevated thyroid hormone receptor alpha (THRA) and type 2 deiodinase (dio2). As the protein encoded by THRA is a nuclear hormone receptor for $\mathrm{T} 3$, these results are consistent with the high T3 levels in pansteatitis-affected fish in the present study. The T3:T4 ratio provides an indirect measure of extrathyroidal conversion of T4 to T3 by deiodination (Brar et al. 2010), and the elevated T3:T4 ratios in the present study are in agreement with the high dio2 levels reported by Truter et al. (2016) in O. mossambicus juveniles of the same population of fish. In hyperthyroidism, colloid stains less intensely; epithelial cell height in-creases and follicles are smaller (Eales et al. 1999). The latter is not consistent with our observations in fish from LR, as their follicles were significantly larger than those from FBR. Elevated T3 levels, reduced colloid staining and hypertrophy of follicle epithelial cells in rats can be attributed to iodine deficiency (Lavado-Autric et al. 2013). However, prolonged exposure to iodine deficiency usually results in decreased T4 levels, which were not observed in fish from LR. The T3 and T4 levels of $O$. mossambicus from FBR, and T4 levels in fish from LR were comparable to control fish used 
Table 4. Stepwise multiple regression beta coefficients $(b)$ and p-values for relationships between nutritional and thyroid parameters measured in steatitis-affected and reference Oreochromis mossambicus. Bold font indicates that the beta coefficient is significant $\left({ }^{*} \mathrm{p}<0.05\right)$; ns: not significant

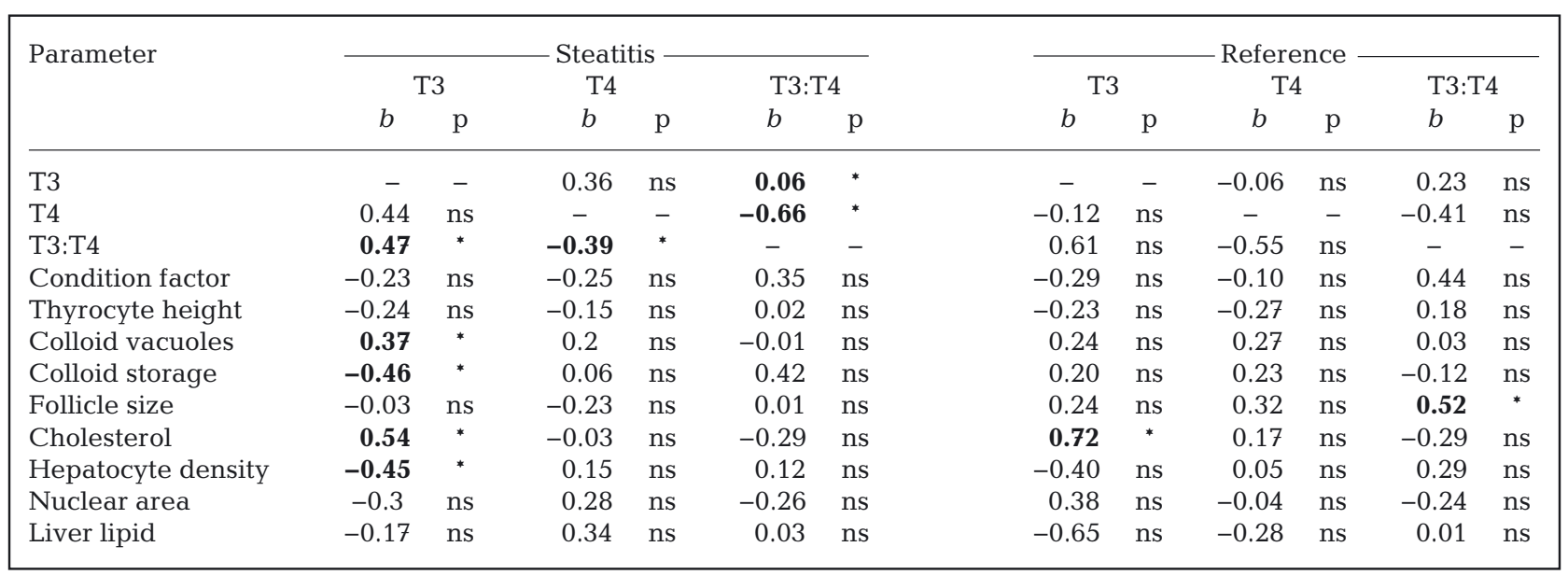

in experimental studies, but T3 levels in LR fish were higher than published values (Peter 2009, Peter \& Peter 2009).

Elevated T3 levels were positively correlated with plasma cholesterol in both steatitis-affected and reference fish. This result suggests a link between lipid metabolism and the thyroid system, and thus this is the first field study to report similar findings to those observed in experimental studies (Narayansingh \& Eales 1975, Sheridan 1986). In steatitis-affected fish, T3 increased as hepatocyte density decreased, which indicates a link between thyroid hormones and the nutritional state of the fish. In the present study, differences in the nutritional state of fish from both populations were observed. The larger hepatocytes, nuclei and higher liver lipid concentrations, along with elevated plasma cholesterol and triglycerides in steatitis-affected fish were all indicative of abundant nutritional intake and energy reserves. These results are consistent with the greater diversity and abundance of food items in the diet of fish from LR compared to those from FBR (Dabrowski et al. 2014a). Furthermore, higher dio2 and adipogenesis-linked peroxisome proliferator-activated receptor gamma expression was reported in O. mossambicus juveniles exposed to unfiltered LR water, compared to filtered water (Truter et al. 2016). The authors attributed the difference to the availability of food in the unfiltered sample, while fish in the filtered sample were essentially fasted for $48 \mathrm{~h}$. Dietary quantity and quality plays an important role in regulating thyroid hormones (Eales 1988, MacKenzie et al. 1998). Higher T3 levels have been reported when fish were fed a high-protein and high-calorie diet compared to equal quantities of a low-protein and low-calorie diet (Higgs \& Eales 1979). Increasing food quantities in Nile tilapia O. niloticus have resulted in significantly higher plasma T3 levels, while T4 levels remained unaffected (Toguyeni et al. 1996). This response effect has been reported in several other fish species (Eales \& Shostak 1985, McCormick \& Saunders 1990) and is comparable to fish from LR, providing strong evidence that their elevated T3 levels may be in response to higher nutritional inputs. The diet of $O$. mossambicus from LR and FBR is well known and was analysed in the same fish assessed for this study (Dabrowski et al. 2014a). There have been no studies to determine the nutritional quality of food sources found to be dominant in LR, such as Ceratium hirundinella. Pansteatitis has been described in fish reared under controlled conditions fed a diet high in polyunsaturated fats and deficient in antioxidants (Roberts \& Agius, 2008). Therefore, knowledge of dietary quality is an important next step in determining the disease aetiology.

In $O$. mossambicus, the expression of hepatic insulin-like growth factor, a mitogenic factor that induces growth and differentiation, is stimulated by increasing T3 levels (Schmid et al. 2003) and could potentially explain the large body size of fish from LR. Elevated T3 levels may also be related to contaminant effects on thyroid function which have been studied in over 40 fish species and extensively reviewed (Rolland 2000, Brown et al. 2004, Carr \& Patiño 2011). Effluent from working and abandoned coal mines, wastewater treatment works, industrial and agricultural sources in the catchment of LR (Dabrowski \& de Klerk 2013) potentially contain 
environmentally relevant chemicals with the ability to modify fish thyroid function (Brown et al. 2004). Previous studies have periodically reported elevated levels of various metals ( $\mathrm{Al}, \mathrm{Fe}$ and $\mathrm{Mn}_{\text {; }}$ Oberholster et al. 2010, Dabrowski et al. 2013), but the presence of organic pollutants has not been assessed in any fish or water from LR. Future studies are required to confirm the factors that underlie the homeostatic shift that leads to elevated plasma and liver lipids and T3 levels in fish from LR.

Seasonal increases in plasma T3 and T4 in spring and summer were observed in fish from both populations. In addition to variation in feeding rates, this pattern may be related to reproductive processes, as thyroid hormones are known to be elevated during gonadal development (Arcand-Hoy \& Benson 1998) which would occur at this time of year. The active mobilisation of lipid reserves can occur during distinct periods in the biological cycle of fish, e.g. fasting periods during winter months, and the gonad development phase (Corraze 2001). Elevated cholesterol and triglyceride levels in female fish from both reservoirs in spring and summer may be related to increased feeding rates and/or reproductive cycles. Cholesterol in particular is converted to various classes of gonadal steroids by steroidogenic enzymes (Young et al. 2005), and in females large amounts of fat are mobilised during the formation of ovaries and their constituent eggs (Tocher 2003). During winter, $50 \%$ of fish stomachs from LR were empty, but only $20 \%$ from FBR (Dabrowski et al. 2014a), which indicated that fish from LR and FBR were still actively feeding in winter despite low temperatures $\left(<16^{\circ} \mathrm{C}\right.$ at $\mathrm{LR}_{i} 19^{\circ} \mathrm{C}$ at $\mathrm{FBR}$ ) and explains the maintenance of plasma lipid levels relative to other seasons.

Thyroid activity (except T4 levels) and nutritional status were reduced in reference fish from FBR compared to fish from LR. Fish from FBR have access to a restricted diet dominated by detritus and sediment (Dabrowski et al. 2014a). In contrast to fish from LR, their T3 values were consistently lower than T4, which has been reported for control values of $O$. mossambicus in previous laboratory-based studies (Weber et al. 1992, van Anholt et al. 2003, Peter \& Peter 2009), and is the general pattern reported for most fish species (Power et al. 2001). Their liver lipid values, although significantly lower than fish from LR, were indicative that energy stores were present and available for mobilisation. Their plasma cholesterol was within the reference intervals for Oreochromis hybrids (Hrubec et al. 2000), and triglycerides were comparable to those of male fish from LR. The T4 levels of food-restricted fish have mostly been shown to decrease (Eales 1988, Power et al. 2000), but increased levels have also been reported (Toguyeni et al. 1996). The fact that T4 levels were similar in fish from both reservoirs suggests that food restriction was not affecting fish from FBR. We conclude that although fish from FBR had lower nutritional inputs and energy reserves, these were not indicative of nutritional stress.

The current study has shown that steatitis-affected fish from LR have highly active thyroid function, and all indicators of nutritional status suggested high nutritional intake and energy storage. The cooccurrence of these states was linked by positive correlations between plasma lipids and T3. However, the link was non-directional and could not indisputably confirm whether elevated thyroid function was the result of fish nutritional state or other factors. It was also not possible to confirm whether their nutritional state was simply due to high nutritional inputs, or the result of dysfunctional metabolic processes unrelated to the thyroid cascade. Although evidence for a nutritionally stimulated thyroid axis is good for fish from LR, endocrine disruption cannot be ruled out until further research has been conducted. This should include other aspects involved in the process of energy homeostasis such as the expression of various lipases and hormones such as ghrelin that are known to stimulate feeding and fat deposition in O. mossambicus (Riley et al. 2005). Observed variation related to seasons and gender may be associated with reproductive state, which was not determined in this study, but should be considered in future.

Acknowledgements. We sincerely thank J. M. Dabrowski, A. Hoffman and N. Lübcker for their assistance with fieldwork. The financial assistance of the National Research Foundation (NRF) towards this research is hereby acknowledged. Opinions expressed and conclusions arrived at are those of the authors and are not necessarily to be attributed to the NRF.

\section{LITERATURE CITED}

Arcand-Hoy LD, Benson WH (1998) Fish reproduction: an ecologically relevant indicator of endocrine disruption. Environ Toxicol Chem 17:49-57

Ashton PJ, Dabrowski JM (2011) An overview of surface water quality in the Olifants River catchment. WRC Rep KV293/11. Water Research Commission, Pretoria

Bancroft JD, Gamble M (2002) Theory and practice of histological techniques, 5th edn. Churchill Livingstone, Philadelphia, PA

*Begg GS, Bruno DW, McVicar AH (2000) The histopathology and ultrastructure of steatitis affecting common dab Limanda limanda. Dis Aquat Org 41:123-133 
Brar NK, Waggoner C, Reyes JA, Fairey R, Kelley KM (2010) Evidence for thyroid endocrine disruption in wild fish in San Francisco Bay, California, USA. Relationships to contaminant exposures. Aquat Toxicol 96:203-215

Bricknell IR, Bruno DW, Bowden TJ, Smith P (1996) Fat cell necrosis syndrome in Atlantic halibut, Hippoglossus hippoglossus L. Aquaculture 144:65-69

Brown SB, Adams BA, Cyr DG, Eales JG (2004) Contaminant effects on the teleost fish thyroid. Environ Toxicol Chem 23:1680-1701

Carr JA, Patiño R (2011) The hypothalamus-pituitary-thyroid axis in teleosts and amphibians: endocrine disruption and its consequences to natural populations. Gen Comp Endocrinol 170:299-312

Corraze G (2001) Lipid nutrition. In: Guillaume J, Kaushik $\mathrm{S}$, Bergot $\mathrm{P}$, Metailler R (eds) Nutrition and feeding of fish and crustaceans. Springer-Praxis, New York, NY, p 116

Dabrowski JM, de Klerk LP (2013) An assessment of the impact of different land use activities on water quality in the upper Olifants River catchment. Water SA 39: 231-244

Dabrowski J, Oberholster PJ, Dabrowski JM, Le Brasseur J, Gieskes J (2013) Chemical characteristics and limnology of Loskop Dam on the Olifants River (South Africa), in light of recent fish and crocodile mortalities. Water SA 39:675-686

Dabrowski J, Hall G, Lubcker N, Oberholster PJ, Phillips DL, Woodborne S (2014a) Piscivory does not cause pansteatitis (yellow fat disease) in Oreochromis mossambicus from an African subtropical reservoir. Freshw Biol 59:1484-1496

Dabrowski J, Oberholster PJ, Dabrowski JM (2014b) Water quality of Flag Boshielo Dam, Olifants River, South Africa: historical trends and the impact of drought. Water SA 40:345-357

DMR (Department of Mineral Resources) (2009) Developments in the economic contribution of hydrocarbons, natural gas and coal. Report 78/2009. Directorate: Mineral Economics, Pretoria

Eales JG (1988) The influence of nutritional state on thyroid function in various vertebrates. Integr Comp Biol 28: 351-362

Eales JG, Brown SB (1993) Measurement and regulation of thyroidal status in teleost fish. Rev Fish Biol Fish 3: 299-347

Eales JG, Shostak S (1985) Correlations between food ration, somatic growth parameters, and thyroid function in Arctic charr Salvelinus alpinus L. Comp Biochem Physiol A 80:553-558

Eales JG, Brown SB, Cyr DG, Adams BA, Finnson KR (1999) Deiodination as an index of chemical disruption of thyroid hormone homeostasis and thyroidal status in fish. In: Henshel DS, Black MC, Harrass MC (eds) Environmental toxicology and risk assessment: standardization of biomarkers for endocrine disruption and environmental assessment, Vol 8. ASTM STP 1364. American Society for Testing and Materials, West Conshohocken, PA, p 136-141

Ferreira S, Pienaar D (2011) Degradation of the crocodile population in the Olifants River gorge of Kruger National Park, South Africa. Aquat Conserv 21:155-164

Fischer AH, Jacobson KA, Rose J, Zeller R (2008) Hematoxylin and eosin staining of tissue and cell sections. Cold Spring Harbor Protoc 2008:pdb-prot4986
Folch J, Lees M, Sloane-Stanley GH (1957) A simple method for the isolation and purification of total lipids from animal tissue. J Biol Chem 226:497-509

Fytianou A, Koutinas AF, Saridomichelakis MN, Koutinas CK (2006) Blood $\alpha$-tocopherol, selenium and glutathione peroxidase changes and adipose tissue fatty acid changes in kittens with experimental steatitis (yellow fat disease). Biol Trace Elem Res 112:131-143

Goodwin AE (2006) Steatitis, fin loss and skin ulcers of channel catfish, Ictalurus punctatus (Rafinesque), fingerlings fed salmonid diets. J Fish Dis 29:61-64

* Guarda F, Bertoja G, Zoccarato I, Tartari E, Biolatti B (1997) Spontaneous steatitis of epicardial fat in farmed white sturgeon (Acipenser transmontanus). Aquaculture 158: $167-177$

*Herman RL, Kircheis FW (1985) Steatitis in Sunapee trout, Salvelinus alpines oquassa Girard. J Fish Dis 8: 237-239

KHiggs DA, Eales JG (1979) The influence of diet composition on radiothyroxine kinetics in brook trout, Salvelinus fontinalis (Mitchill). Can J Zool 57:396-402

* Hrubec TC, Cardinale JL, Smith SA (2000) Hematology and plasma chemistry reference intervals for cultured tilapia (Oreochromis hybrid). Vet Clin Pathol 29:7-12

*Huchzermeyer KDA, Govender D, Pienaar D, Deacon AR (2011) Steatitis in wild sharptooth catfish, Clarius gariepinus (Burchell), in the Olifants and lower Letaba Rivers in the Kruger National Park, South Africa. J Fish Dis 34:489-498

Lall SP (2010) Disorders of nutrition and metabolism. In: Leatherland JF, Woo PTK (eds) Fish diseases and disorders. Vol 2: Non-infectious disorders, 2nd edn. CAB International, Wallingford, p 202-204

* Lavado-Autric R, Calvo R, Martinez de Mena R, Morreale de Escobar G, Obregon MJ (2013) Deiodinase activities in thyroids and tissues of iodine-deficient female rats. Endocrinology 154:529-536

Lu K, Xu W, Li J, Li X, Huang G, Liu W (2013) Alterations of liver histology and blood biochemistry in blunt snout bream Megalobrama amblycephala fed high-fat diets. Fish Sci 79:661-671

*MacKenzie DS, VanPutte CM, Leiner KA (1998) Nutrient regulation of endocrine function in fish. Aquaculture 161:3-25

* McCormick SD, Saunders RL (1990) Influence of ration level and salinity on circulating thyroid hormones in juvenile Atlantic salmon (Salmo salar). Gen Comp Endocrinol 78: $224-230$

Narayansingh T, Eales JG (1975) The influence of physiological doses of thyroxine on the lipid reserves of starved and fed brook trout, Salvelinus fontinalis (Mitchill). Comp Biochem Physiol B 52:407-412

Nugegoda D, Kibria G (2017) Effects of environmental chemicals on fish thyroid function: implications for fisheries and aquaculture in Australia. Gen Comp Endocrinol 244:40-53

\% Oberholster PJ, Myburgh JG, Ashton PJ, Botha AM (2010) Responses of phytoplankton upon exposure to a mixture of acid mine drainage and high levels of nutrient pollution in Lake Loskop, South Africa. Ecotoxicol Environ Saf 73:326-335

* Orós J, Monagas P, Calabuig P, Luzardo OP, Camacho M (2013) Pansteatitis associated with high levels of polychlorinated biphenyls in a wild loggerhead sea turtle Caretta caretta. Dis Aquat Org 102:237-242 
Peter MCS, Peter VS (2009) Action of thyroid inhibitor propyl thiouracil on thyroid and interregnal axes in the freshwater tilapia Oreochromis mossambicus Peters. J Endocrinol Reprod 13:37-44

Peter VS (2009) Stress response in Mozambique tilapia (Oreochromis mossambicus): temporal and inverse interaction of cortisol and thyroid hormone when confined to net. J Endocrinol Reprod 13:87-96

Power DM, Melo J, Santos CRA (2000) The effect of food deprivation and refeeding on the liver, thyroid hormones and transthyretin in sea bream. J Fish Biol 56: 374-387

Power DM, Llewellyn L, Faustino M, Nowell MA and others (2001) Thyroid hormones in growth and development of fish. Comp Biochem Physiol C Toxicol Pharmacol 130: 447-459

Riley LG, Fox BK, Kaiya H, Hirano T, Grau EG (2005) Longterm treatment of ghrelin stimulates feeding, fat deposition, and alters the GH/IGF-I axis in the tilapia, Oreochromis mossambicus. Gen Comp Endocrinol 142: 234-240

Roberts RJ, Agius C (2008) Pansteatitis in farmed northern bluefin tuna, Thunnus thynnus (L.), in the eastern Adriatic. J Fish Dis 31:83-88

Roberts RJ, Richards RH, Bullock AM (1979) Pansteatitis in rainbow trout Salmo gairdneri Richardson: a clinical and histopathological study. J Fish Dis 2:85-92

Rolland RM (2000) A review of chemically-induced alterations in thyroid and vitamin A status from field studies of wildlife and fish. J Wildl Dis 36:615-635

Schmid AC, Lutz I, Kloas W, Reinecke M (2003) Thyroid hormone stimulates hepatic IGF-I mRNA expression in a bony fish, the tilapia Oreochromis mossambicus, in vitro and in vivo. Gen Comp Endocrinol 130:129-134

Sheridan MA (1986) Effects of thyroxine, cortisol, growth hormone, and prolactin on lipid metabolism of coho salmon, Oncorhynchus kisutch, during smoltification. Gen Comp Endocrinol 64:220-238

Strüssmann CA, Takashima F (1990) Hepatocyte nuclear size and nutritional condition of larval pejerrey, Odontes- thes bonariensis (Cuvier et Valenciennes). J Fish Biol 36: $59-65$

Suarez-Bonnet A, de los Monteros AE, Herraez P, Rodriguez F, Andrada M, Caballero MJ (2008) Fat embolism secondary to yellow fat disease in an Appaloosa horse. J Vet Diagn Invest 20:684-687

* Tocher DR (2003) Metabolism and functions of lipids and fatty acids in teleost fish. Rev Fish Sci 11:107-184

* Toguyeni A, Baroiller JF, Fostier A, Le Bail PY, Kuhn ER, Mol KA, Fauconneau B (1996) Consequences of food restriction on short-term growth variation and on plasma circulating hormones in Oreochromis niloticus in relation to sex. Gen Comp Endocrinol 103:167-175

* Truter JC, van Wyk JH, Oberholster PJ, Botha AM, LuusPowell WJ (2016) The expression of selected genes linked to metabolic homeostatis in obese pansteatitissuffering Mozambique tilapia, Oreochromis mossambicus (Peters). J Fish Dis 39:69-85

*Van Anholt RD, Spanings T, Koven W, Wendelaar Bonga SE (2003) Effects of acetylsalicylic acid treatment on thyroid hormones, prolactins, and the stress response of tilapia (Oreochromis mossambicus). Am J Physiol Regul Integr Comp Physiol 285:R1098-R1106

*Van der Geyten S, Byamungu N, Reyns GE, Kuhn ER, Darras VM (2005) Iodothyronine deiodinases and the control of plasma and tissue thyroid hormone levels in hyperthyroid tilapia (Oreochromis niloticus). J Endocrinol 184: 467-479

Wahlefeld AW (1974) Triglycerides: determination after enzymatic hydrolysis. Anal Biochem 98:341-345

*Weber GM, Okimoto DK, Richman NH III, Grau EG (1992) Patterns of thyroxine and triiodothyronine in serum and follicle-bound oocytes of the tilapia, Oreochromis mossambicus, during oogenesis. Gen Comp Endocrinol 85:392-404

Young G, Kusakabe M, Nakamura I, Lokman PM, Goetz FW (2005) Gonadal steroidogenesis in teleost fish. In: Melamed P, Sherwood N (eds) Hormones and their receptors in fish reproduction. World Scientific Publishing, Singapore, p 157

Submitted: November 11, 2014; Accepted: May 9, 2017

Proofs received from author(s): June 26, 2017
Editorial responsibility: Bernd Sures, Essen, Germany 